\title{
DETERMINANTS OF REPURCHASE INTENTION AND SWITCHING INTENTION: ANALYSIS OF ONLINE TRAVEL AGENT, PEER-TO-PEER ACCOMMODATION, AND VIRTUAL HOTEL OPERATOR PLATFORMS
}

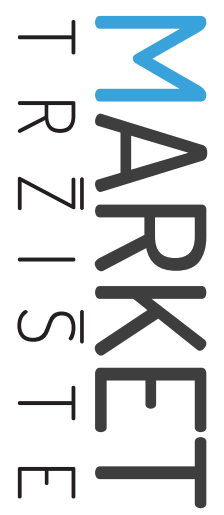

\section{ODREDNICE NAMJERE PONOVNE KUPOVINE I NAMJERE PREBACIVANJA: ANALIZA PLATFORMI ONLINE PUTNIČKIH AGENATA, SMJEŠTAJA (U VLASNIŠTVU) RAVNOPRAVNIH KORISNIKA (ENG. PEER-TO-PEER ACCOMMODATION) TE VIRTUALNIH HOTELSKIH OPERATORA}

Market-Tržište

Vol. 32, No. 1, 2020, pp. 79-96

UDK 658.89:004.031.4:640.41:338.486.22

DOI http://dx.doi.org/10.22598/mt/2020.32.1.79

Preliminary communication

\section{Andrianto Prasetya Nugroho a , Sri Rahayu Hijrah Hati}

a University of Indonesia, Faculty of Economics and Business, Dekanat Building FEB UI, Widjojo Nitisastro Campus, Depok, INDONESIA 16424, e-mail: andryprasetya24@gmail.com

b University of Indonesia, Faculty of Economics and Business, Dekanat Building FEB UI, Widjojo Nitisastro Campus, Depok, INDONESIA 16424

\section{Abstract}

Purpose - The aim of this research is to analyze the relationship between satisfaction, trust, repurchase intention, and switching intention in online-booking hotel platforms.

Design/methodology/approach - The research involved 600 respondents who have ever used an online-booking hotel platform in all stages of the transaction process (from the start until the end of service).

\section{Sažetak}

Svrha - Cilj je istraživanja analizirati odnos između zadovoljstva, povjerenja, namjere ponovne kupovine $\mathrm{i}$ namjere prebacivanja na platformama za rezervaciju smještaja putem interneta.

Metodološki pristup - Istraživanjem je obuhvaćeno 600 ispitanika koji su koristili uslugu platforme za rezervaciju smještaja putem interneta u svim fazama transakcijskog procesa (od početka do kraja usluge). Korišten je 
The purposive sampling method was used, and the data were analyzed by using structural equation modeling (LISREL).

Findings and implications - The results show similarities in positive relationship between variables in the three types of platform. Those were experience-based satisfaction and disposition to trust, experience-based satisfaction and institution-based trust, transaction-based satisfaction and experience-based satisfaction, transaction-based satisfaction and institution-based trust, transaction-based satisfaction and repurchase intention, and institution-based trust and disposition to trust. The implication is that industry professionals operating online travel agent platforms should not neglect transaction-based satisfaction as it has significant effects on switching intention, repurchase intention, and institution-based trust.

Limitation - Respondents in this study only included Indonesian residents, booking with companies in Indonesia. The findings in this study cannot represent conditions around the world.

Originality - Most studies on hospitality and tourism only explore one online booking platform as their object although different platforms can provide different findings. This paper contributes to the existing literature by dividing online booking platforms into three types: online travel agency, peer-to-peer accommodation, and virtual hotel operator.

Keywords - Airbnb, online travel agency, online-booking hotel, peer-to-peer accommodation, repurchase intention, satisfaction, trust namjerni uzorak, a podaci su analizirani pomoću modeliranja strukturnih jednadžbi (LISREL).

Rezultati i implikacije - Rezultati pokazuju da postoje sličnosti u pozitivnom odnosu između varijabli na trima vrstama platformi. To su odnosi: zadovoljstvo zasnovano na iskustvu i sklonost povjerenju; zadovoljstvo zasnovano na iskustvu i povjerenje prema instituciji; zadovoljstvo zasnovano na transakciji i zadovoljstvo zasnovano na iskustvu; zadovoljstvo zasnovano na transakciji i povjerenje prema instituciji, zadovoljstvo zasnovano na transakciji i namjera ponovne kupovine te, kao posljednje, povjerenje prema instituciji i sklonost povjerenju. Implikacija za profesionalce $u$ industriji online putničkih agenata jest da ne bi trebali zanemariti zadovoljstvo zasnovano na transakciji jer ono ima značajne učinke na namjeru prebacivanja, namjeru ponovne kupnje te na povjerenje vezano uz instituciju.

Ograničenja - U Istraživanje su uključeni samo ispitanici i poduzeća iz Indonezije. Nalazi istraživanja se ne mogu generalizirati na svjetskoj razini.

Doprinos - U većini istraživanja o ugostiteljstvu i turizmu objekt istraživanja je samo jedna platforma za rezervacije putem interneta. Međutim različite platforme mogu pružiti i različite rezultate. Ovaj rad doprinosi postojećoj literaturi dijeljenjem platformi za online rezervaciju smještaja na tri vrste: online putnička agencija, smještaj (u vlasništvu) ravnopravnih korisnika (engl. peer-to-peer accommodation) te virtualni hotelski operator.

Ključne riječi - Airbnb, online putnička agencija, rezervacija hotela putem interneta, smještaj (u vlasništvu) ravnopravnih korisnika (engl. peer-to-peer accommodation), namjera ponovne kupnje, zadovoljstvo, povjerenje 


\section{INTRODUCTION}

Disruptive innovation has penetrated various fields of the services industry in the world, ranging from the music industry, which allows music lovers to no longer use cassettes; instead, they can listen and download digital music through online media. Recently, such innovation has also emerged in transportation industry, allowing consumers to book transportation services through online applications via mobile phones as part of a phenomenon commonly called sharing economy (Guttentag, 2015).

The increasing variety of business models and the development of the concept of sharing economy have made online-based consumer behavior more complicated. According to Botsman and Rogers (2010), consumers are now eager to participate in the economic concept of sharing business, trading all possible resources they have with foreigners, including renting out their homes like hotels.

Airbnb is among the most successful companies in the world that use an online accommodation business model (peer-to-peer accommodation). Airbnb is an online platform that allows someone to rent out their rooms as hosts, while enabling another person to book those rooms as guests through websites or mobile phone applications. The difference between Airbnb and an online travel agent (OTA) such as Booking.com or Traveloka (in Indonesia) is that Airbnb allows individuals who do not have business entities (such as hotels) to offer their room accommodation service to the tourists (Tussyadiah, 2016).

Hotel business also has other alternatives in selling and promoting their accommodation to counter booking problems. Among those are cooperating with an OTA or a virtual hotel operator (VHO). OTA is a tourist agency that utilizes the advantage of information technology through the Internet. OTA provides a system that can unite hotels and consumers (as a marketplace). Being application-based, it can reach consumers quickly and broadly. Also, OTAs can organize the transaction and payment system (Inversini \& Lorenzo, 2013).

Nowadays, the tourism and hospitality industry is developing rapidly, as showed by the number of start-up companies that continue to enliven the market - both the markets with many players and niche markets that have not been covered by a number of businesses. Such conditions have allowed the $\mathrm{VHO}$ business model to develop as a new option for both consumers and hoteliers to market their rooms.

VHOs in Indonesia were initially introduced by Nida Rooms, the first and largest $\mathrm{VHO}$ company in the ASEAN (CNN Indonesia, 2016). The company will look for lodging business partners (hotels and apartments) whose occupancy rates are still not optimal. Then, the company and partners will reach an agreement to sell the room under the company's brand. In addition, the $\mathrm{VHO}$ company also sets standards that must be met by partners; for example, every room that is marketed must have AC and Wi-Fi facilities. Through the agreement, independent hotels or small hotels can be helped in marketing their rooms (DailySocial.id, 2015).

Today's marketing science concept assumes that relationship marketing is the most important aspect in developing and evaluating company relationships with their customers (Berry, 1995). This phenomenon arises because relationship marketing can attract, maintain, and develop the company's relations with customers (Berry, 2002). To implement the relationship marketing, a company's decision is adjusted by the level of competition, so the company tends to change its focus and adjust to the customer (customer-oriented) (Kotler \& Keller, 2012). This requires the ability of the company to have a better understanding of what its customer needs. Those can be reflected through the level of customer satisfaction that is derived from transaction activities with the company. Customer satisfaction is believed to be one of the most important aspects in establishing relationships with consumers, because customer satisfaction really focuses on the customer's

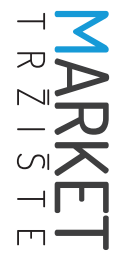


perceived point of view (truly customer-oriented) (Cengiz, 2010).

Another aspect that is considered to be among the most important aspects of relationship marketing is trust. Trust is believed to have the potential of making a good contribution to maintaining company relations with their customers in the long term (Trif, 2013). Especially in the context of online transactions, trust is seen as being able to minimize the level of uncertainty that customers feel when establishing online transaction activities (Pavlou, Liang \& Xue, 2007). Companies try to build important aspects that they believe can increase repurchase intention and reduce switching intention. However, the customer's assessment of these aspects may differ depending on the type of the business model employed and accommodation itself. Companies cannot necessarily apply the same strategy to different types of accommodation.

According to several facts and data that have been presented, this study focused on such aspects that can build repurchase intention and switching intention through satisfaction and trust in the three different types of online hotel-booking platforms; those were peer-topeer accommodation, OTA, and VHO. Satisfaction was measured from two different perspectives: transaction-based satisfaction, and experience-based satisfaction. Trust was also divided into two different perspectives: institution-based trust, and disposition to trust.

\section{LITERATURE REVIEW}

\subsection{Peer-to-peer accommodation}

Peer-to-peer accommodation allows someone to rent out all or part of their property over a short period of time. This concept of accommodation provides more destination options for tourists while increasing the period of time to stay, the number of travel frequencies, and the number of activities (entertainment) that tourists can visit at their destination.
Peer-to-peer accommodation is different from traditional accommodation sectors from various aspects. From the supply side, the accommodation is provided by non-professionals or the general public, with flexible resources, low market entry fees, and usually not generating the main income but additional sources of income (Guttentag, 2015). On the demand side, consumers can look for lodging at a more affordable price, property with a wider type of room, a comfortable environment (far from urban areas), and can have the opportunity to experience the hospitality and local lifestyle of the hosts (Liang, Hwansuk \& Marion, 2018). According to Tussyadiah and Pesonen (2016), there are two main factors that encourage a person to use peer-to-peer accommodation services: social appeal (the desire to engage in community activities) and the economic appeal (the priority to lower costs). The obstacles include the issues of trust, knowledge of the system, and the quality of service.

\subsection{Online travel agency}

Online travel agency or OTA is a business model that has also grown and developed rapidly thanks to the quality, capabilities, and the speed of the Internet. In the hotel industry, OTA plays a very crucial role in its ability to distribute hotel rooms online (Inversini \& Lorenzo, 2013). OTA is a third-party company (marketplace) that connects various hotels with consumers in one platform. Along with the development of the tourism and online travel industries, the existence of OTA is very strong, compared with that of the hotels themselves in terms of providing information and financial strength (Morosan \& Jeong, 2008).

The advantage of accessing hotel information through OTA is that consumers can directly compare room rental prices of various hotels. Besides that, OTA also provides the convenience of 24/7 access time flexibility and an always updated content (Kim, Kim \& Han, 2007). In addition, OTA also has a system of reviewing experiences from consumers who have visited the hotel. 
OTA works like a transaction broker (Lee \& Morrison, 2010) which is responsible for ensuring smooth and easy transactions between consumers and the hotel by providing an organized payment system. The main income is obtained from the cost per transaction; thus, when a consumer decides to use hotel services by making a credit card payment through an online system, OTA will get a fee from each successful transaction.

\subsection{Virtual hotel operator}

VHOs basically have no assets in the form of hotels. This business concept develops like that of an Uber company in the field of transportation, but the $\mathrm{VHO}$ company collaborates with its partners to help promote the lodging on their platform. The $\mathrm{VHO}$ company sets a standard for its partners; then the lodging or rooms will be marketed under the name of the company (Kesharwani \& Vivek, 2016).

This business model employs a concept of investing not in the property or assets owned, but rather in the marketing and management system to improve the quality of accommodation offered under a partnership agreement with the VHO company. VHOs offer aspects that budget hotels do not generally have, such as networks, knowledge, marketing capabilities which prevent these hotels from maximizing their occupancy rates. Besides, VHO companies will typically collaborate with budget hotel partners by providing several benefits, such as setting standards for clean and comfortable rooms, providing quality control and control, and training to their employees (Kesharwani \& Vivek, 2016).

\subsection{Customer satisfaction}

\subsubsection{Transaction-based satisfaction}

Transaction-based satisfaction tries to focus on the level of satisfaction of a person based on a more specific transaction experience. Liang et al. (2018) built the term transaction-based satisfaction based on the development of the study at the level of satisfaction that discusses more specific aspects. Initially, Bitner and Hubbert (1994) stated that someone's satisfaction must be explored more specifically as encounter satisfaction and overall satisfaction. They described the encounter satisfaction as the level of satisfaction that customers feel about their interaction with the role of the company's service encounter. Overall satisfaction is more about the level of satisfaction customers feel toward the overall activity of the organization.

Business models that use online transaction activities such as OTAs, peer-to-peer accommodation, and $\mathrm{VHO}$ s certainly need knowledge about customer evaluations of the transaction process. In this business model, customers are faced with two different parties: companies and hosts (company's hotel partners), so the role of the company's online-booking platform in this context can be evaluated only through transaction activities between companies and customers because, basically, they do not meet directly.

\subsubsection{Experience-based satisfaction}

According to Liang et al. (2018), satisfaction can also be evaluated through other specific experiences; the term is known as experience-based satisfaction. Especially in this research model, the experience-based satisfaction aspect evaluates the level of customer satisfaction when they interact with the host and their stay experience. The development is based on the findings of Woodruff, Cadotte, and Jenkins (1983), who concluded that customers make comparisons of the experiences that have been felt with the current situation to measure the level of satisfaction.

\subsection{Trust (institution-based and disposition to trust)}

Trust is defined as a feeling of security based on the belief that good and positive intentions give mutual welfare to one another, not by lying behavior or taking advantage of others' weaknesses (Moorman, Zaltman \& Deshpande, 1992). Bicchieri, Duffy, and Tolle (2004) define trust as a state of a person who is in a position to engage in social exchanges that contain elements of uncertainty and vulnerability but can potentially benefit both parties.

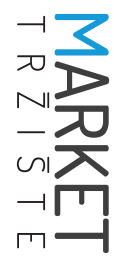




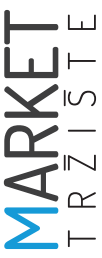

Trust can be an important aspect that encourages a person to conduct tourism transactions online, because of a high risk between the two parties in divulging financial information and personal information during the transaction process (Bart, Venkatesh, Sultan \& Urban, 2005). According to Lau and Lee, if one party trusts the other, it will result in a positive attitude toward others. Trust will affect credibility; in turn, credibility will ultimately have an impact on one's long-term orientation toward others by reducing risk perceptions related to business benefits (Erdem, Louviere \& Swait, 2002).

In the transaction model developed by the hotel online-booking platform, customers are faced with two different parties: the company that provides the online hotel reservation platform and the host. Therefore, trust has a variety of evaluations on these two sides. In this study, trust in the company was taken to be institutional-based trust, whereas trust in the host was called disposition to trust. McKnight, Choudhury, and Kacmar (2002) realized that trust plays a very important role in helping customers to deal with and minimize the risks that arise because of uncertainty in online sales transaction activities. Therefore, they applied the initial trust-building model on e-commerce platforms and developed several measurement variables, namely, disposition to trust, institution-based trust, trusting belief, and trust intention.

Disposition to trust can be intended at the level of customer confidence or trust in service providers guaranteed by intermediaries (companies) in aspects of the application of fair rules and procedures, and good results in the market to assure customers that sellers can act consistently and in accordance with what is to be expected (McKnight, Cummings \& Chervany, 1998).

\subsection{Repurchase intention}

Repurchase intention refers to a person's behavior that allows that person to buy or reuse the same product or service more than once (Peyrot \& Van Doren, 1994). Most consumers who successfully buy products or services are potential- ly consumers who will make repeat purchases. Consumers will have a commitment after purchasing a product or service. The commitment is formed because of a positive impression of a product, so consumers feel satisfied making the purchase (Hicks, Page Jr., Behe, Dennis \& Fernandez, 2005).

Davis (1989) argues that repurchase intention is defined as a possibility that can occur in each individual to repurchase from the same seller. Through these purchases, consumers evaluate the values and attributes obtained through products or services purchased. This can lead to behavioral tendencies to like a product and can encourage consumers to form an attitude about the product. This form of attitude is used as a basis to produce repurchase intention.

\subsection{Switching intention}

Switching intention is strongly influenced by the poor quality of service obtained by customers, which leads to the low level of customer satisfaction. Jang, Cho, and Kim (2013) analyzed the effects of negative emotions on dissatisfaction and behavioral intentions. They pointed out that regret and disappointment are very important in generating customer dissatisfaction, which in turn causes negative word-of-mouth and switching to another service provider (switching intention). Keaveney (1995) defines switching intention as a psychological process in customers when they plan to switch from a brand they originally used to another brand or when they intend to stop buying the current brand. For companies, this is a significant loss.

\section{HYPOTHESES DEVELOPMENT}

The mediation model of trust between satisfaction and repurchase intention has been studied previously. Among the research studies found in the literature, that conducted by Fang et al. (2014) found that trust acts as a mediator variable between satisfaction and repurchase intention with various moderating variables. Based on 
that explanations, this research model employed trust as the mediator between satisfaction and repurchase intention and switching intention.

The research developed by Shihab, Maulana, and Hidayanto (2018), which discussed the C2C e-commerce platform, concluded that satisfaction, especially for merchants, had a direct relationship to repurchase intention; however, satisfaction with the company did not affect repurchase intention. According to that research, this study focused on the relationship between satisfaction (transaction-based and experience-based) and repurchase intention and switching intention, as well as the effect of institution-based trust and disposition to trust on repurchase intention and switching intention.

The research model employed by Liang et al. (2018) discussed the relationship of satisfaction and trust on repurchase intention and switching intention, where satisfaction and trust were studied from two aspects: transaction-based satisfaction that focuses on evaluating customer satisfaction at the process and transaction activities with the company on the one hand, and experience-based satisfaction that focuses on evaluating the staying experience and its interaction with the host on the other hand. Trust is divided into institution-based trust, which focuses on evaluating the level of customer trust in online lodging reservation service companies, and disposition to trust, which focuses on evaluating the level of trust in the host. On the basis of some earlier explanations, several hypotheses were developed in this study as follows:

Experience-based satisfaction has a relationship with:

O disposition to trust (positive) - H1a;

$\mathrm{O}$ institution-based trust (positive) - $\mathrm{H} 1 \mathrm{~b}$;

O switching intention (negative) - $\mathrm{H} 1 \mathrm{c}$;

o repurchase intention (positive) - $\mathrm{H} 1 \mathrm{~d}$.

Transaction-based satisfaction has a relationship with:

O experience-based satisfaction (positive) $\mathrm{H} 2 \mathrm{a}$;
O disposition to trust (positive) - H2b;

$\mathrm{O}$ institution-based trust (positive) - $\mathrm{H} 2 \mathrm{c}$;

$\mathrm{O}$ switching intention (negative) - $\mathrm{H} 2 \mathrm{~d}$;

o repurchase intention (positive) - H2e.

Shihab et al. (2018) explored the direct relationship of trust variables with repurchase intention. The findings showed that trust especially toward the company had a direct impact on repurchase intention, but no influence of trust in merchants on repurchase intention could be found. Besides, Jia, Cegielski, and Zhang (2014) conducted a study that discussed online sales through platform intermediaries. The focus of this research was on the exploration of the effect of trust both in platform intermediaries and in online sellers on repurchase intention. The findings concluded that trust in platforms affects trust in online sellers, and their effect on repurchase intention too. In line with the previous studies, the following other hypotheses were developed in this research:

Disposition to trust has a relationship with:

$\mathrm{O}$ switching intention (negative) - $\mathrm{H} 3 \mathrm{a}$;

o repurchase intention (positive) - H3b.

Institution-based trust has a relationship with:

O disposition to trust (positive) - H4a;

O switching intention (negative) - H4b;

o repurchase intention (positive) - H4c.

\section{METHODOLOGY}

\subsection{Measurement development}

The items used for developing the instrument to measure the research model were adapted from existing literature. The items for measuring transaction-based satisfaction were adapted from Liang et al. (2018), Shankar, Smith and Rangaswamy (2003), Park and Young (2003), and Huang and Robert (2011) with a total of 6 questions. The items for measuring experience-based satisfaction were adapted from Liang et al. (2018) and Gao and Ka Wai Lai (2015), 


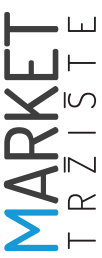

resulting in 6 questions. Whereas the items used to measure institution-based trust and disposition to trust were adapted from Liang et al. (2018) and Matute-Vallejo, Polo-Redondo, and Utrillas (2016), each construct was measured with 6 questions. The items used to measure repurchase intention were developed from Liang et al. (2018), Han, Kim, and Hyun (2011), and Thong, Hong, and Tam (2006), whereas switching intention items were developed from Kim, Kim, and Yoonjoung Heo (2017) and Liang et al. (2018), each with 3 questions.

\subsection{Research design and sampling}

The research model was tested using data collected from customers, based on the three different platforms in online hotel reservations in Indonesia: OTA, peer-to-peer accommodation, and $\mathrm{VHO}$. In order to identify target respondents, an online questionnaire was developed, with a screening question used as an opener to get the information about the types of platform that respondents used to make an online reservation the last time. Therefore, the respondents in this study could not report on experiences with different platforms, because what was examined was their last experience using a specific platform.

Purposive sampling technique was used for this study to reach the respondents among the customers who have ever used online hotel reservation services, including all stages of the transaction processes (from the start to end transactions). All of the measuring scales used a 5-point Likert type scale, rating from $1=$ strongly disagree to $5=$ strongly agree. The analytical method used in this study was the structural equation modeling (SEM) method, specifically the covariance-based SEM which uses the estimation method of maximum likelihood.

The first step of the survey was conducted using a pretest to analyze the validity and reliability of the instruments. Thirty respondents were invited to support the pretest, which concluded that all of the instruments were valid and reliable. A total of 600 respondents, divided into three groups of respondents based on types of online hotel reservation platforms, were involved the main survey: 200 respondents of OTA, 200 respondents of peer-to-peer accommodation, and 200 respondents of $\mathrm{VHO}$.

\section{RESULTS}

This research used LISREL for data analysis, employing a two-step analyzing procedure to test the proposed model. Confirmatory factor analysis (CFA) was used to identify the validity of the measuring items, and SEM was performed to examine the model fit and test the hypotheses. The respondent demographic information was divided into several categories, such as gender, age, education, occupation, and the type of hotel-booking platform used the last time.

\subsection{Demographic data}

Among the respondents, 51\% were males and $49 \%$ were females. The age of $50 \%$ of them was in the range of $21-30$ years old, $5 \%$ were 20 years or younger, $31 \%$ were $31-40,11 \%$ were $41-50$, and $3 \%$ were above 50 years old. The majority of the respondents had a bachelor's degree or higher education degrees (78\%). As to the type of work, they varied from private sector employees (30\%), government employees (16\%), entrepreneurs (13\%), housewives (12\%), students or college students (25\%), and others (4\%). Among the OTA respondent group, Traveloka was the company with the greatest number of users in this study (51\%), followed by Agoda (16\%), and the third was Pegi-Pegi (11\%). On the peer-topeer accommodation platform, there was only one company in this research - Airbnb. VHO users were dominated by respondents who used Airy Rooms (46\%) and Red Doorz (32\%) as their online hotel reservation provider.

\subsection{Measurement model}

The test was carried out by using CFA, which showed whether sample data fit a distribution from the population with a normal distribution. Malhotra (2010) suggests several criteria 
that must be met to achieve a good fit: root mean square error of approximation (RMSEA) $\leq$ 0.08; standardized root mean square residual $(\mathrm{SRMR}) \leq 0.05$; comparative fit index $(\mathrm{CFI})>0.90$; normed fit index (NFI) > 0.90; non-normed fit index (NNFI) > 0.90; normed chi-square $\leq 5.00$; parsimonious normed fit index (PNFI) $\geq 0.90$.

CFA used a total 600 respondents from all types of online hotel reservation platforms. In the CFA stage, one of the switching intention items had to be eliminated because the error variance was negative (Haryono, 2017). The resulting goodness-of-fit indices were as follows: RMSEA was 0.067, SRMR amounted to 0.03, CFI was 0.99, NFI stood at 0.98, with the NNFI/TLI at 0.99, normed chi-square at 3.58, and PNFI at 0.88. The results of the goodness-of-fit indicate a good fit of the model with all measurement items.

The validity of the constructs was examined using standardized factor loading (SLF), whereas the reliability of the constructs was examined using composite reliability (CR). Igbaria, Zinatelli, Cragg, and Cavaye (1997) argued that SLF should be greater than 0.5 for a valid construct. A CR value of 0.7 or higher suggests good reliability (Malhotra, 2010). The SLF results for this study ranged from 0.70 to 0.87 , implying that all the indicators had a good validity. CR values ranged from 0.71 to 0.93 , indicating a relatively good reliability of the measuring constructs (Table 1).

Convergent validity was examined using the average variance extracted (AVE) for each construct that should exceed 0.5 (Fornell \& Larcker, 1981). Table 1 shows that all values of AVE came it above 0.5 , which means more than $50 \%$ of the variance of the instrument item can be measured by the latent variables. Therefore, convergent validity was achieved. The bivariate correlations between all constructs is shown in Table 2 with a standardized path shown in Figure 1. The square root of AVE is much greater than all other cross-correlations between the constructs, indicating adequate discriminant validity (Fornell \& Larcker, 1981).
TABLE 1: Construct validity and reliability

\begin{tabular}{|c|c|c|c|c|}
\hline Variable & Indicator & SLF & CR & AVE \\
\hline \multirow{6}{*}{$\begin{array}{l}\text { Transaction- } \\
\text { based } \\
\text { satisfaction }\end{array}$} & TBS1 & 0.81 & \multirow{6}{*}{0.92} & \multirow{6}{*}{0.67} \\
\hline & TBS2 & 0.79 & & \\
\hline & TBS3 & 0.83 & & \\
\hline & TBS4 & 0.83 & & \\
\hline & TBS5 & 0.83 & & \\
\hline & TBS6 & 0.81 & & \\
\hline \multirow{6}{*}{$\begin{array}{l}\text { Experience- } \\
\text { based } \\
\text { satisfaction }\end{array}$} & EBS1 & 0.85 & \multirow{6}{*}{0.92} & \multirow{6}{*}{0.67} \\
\hline & EBS2 & 0.80 & & \\
\hline & EBS3 & 0.81 & & \\
\hline & EBS4 & 0.84 & & \\
\hline & EBS5 & 0.82 & & \\
\hline & EBS6 & 0.81 & & \\
\hline \multirow{6}{*}{$\begin{array}{l}\text { Institution- } \\
\text { based trust }\end{array}$} & IBT1 & 0.82 & \multirow{6}{*}{0.93} & \multirow{6}{*}{0.70} \\
\hline & IBT2 & 0.83 & & \\
\hline & IBT3 & 0.86 & & \\
\hline & IBT4 & 0.83 & & \\
\hline & IBT5 & 0.84 & & \\
\hline & IBT6 & 0.85 & & \\
\hline \multirow{6}{*}{$\begin{array}{l}\text { Disposition } \\
\text { to trust }\end{array}$} & $\mathrm{TIH1}$ & 0.83 & \multirow{6}{*}{0.93} & \multirow{6}{*}{0.71} \\
\hline & $\mathrm{TIH} 2$ & 0.83 & & \\
\hline & $\mathrm{TIH3}$ & 0.87 & & \\
\hline & $\mathrm{TIH} 4$ & 0.86 & & \\
\hline & $\mathrm{TIH} 5$ & 0.86 & & \\
\hline & $\mathrm{TIH6}$ & 0.82 & & \\
\hline \multirow{3}{*}{$\begin{array}{l}\text { Repurchase } \\
\text { intention }\end{array}$} & Rl1 & 0.84 & \multirow{3}{*}{0.87} & \multirow{3}{*}{0.70} \\
\hline & $\mathrm{R} / 2$ & 0.84 & & \\
\hline & $\mathrm{RI3}$ & 0.85 & & \\
\hline \multirow{2}{*}{$\begin{array}{l}\text { Switching } \\
\text { intention }\end{array}$} & $\mathrm{SI} 2$ & 0.70 & \multirow{2}{*}{0.71} & \multirow{2}{*}{0.55} \\
\hline & $\mathrm{SI} 3$ & 0.79 & & \\
\hline
\end{tabular}

Notes: SLF = standardized loading factors; $C R=$ composite reliability; $A V E=$ average variance extracted

TABLE 2: Correlation among constructs and the square root of the AVE

\begin{tabular}{|l|c|c|c|c|c|c|}
\hline & EBS & IBT & DT & RI & SI & TBS \\
\hline EBS & $\mathbf{0 . 8 2}$ & & & & & \\
\hline IBT & 0.61 & $\mathbf{0 . 8 4}$ & & & & \\
\hline DT & 0.60 & 0.61 & $\mathbf{0 . 8 4}$ & & & \\
\hline RI & 0.61 & 0.67 & 0.53 & $\mathbf{0 . 8 4}$ & & \\
\hline SI & 0.03 & 0.04 & 0.01 & 0.03 & $\mathbf{0 . 7 5}$ & \\
\hline TBS & 0.62 & 0.64 & 0.49 & 0.69 & 0.03 & $\mathbf{0 . 8 2}$ \\
\hline
\end{tabular}

\section{Notes:}

1. Diagonal: square root values of the average variance extracted (AVE) in bolds

2. Off-diagonals: correlation among constructs

3. EBS: experience-based satisfaction, IBT: institution-based trust, DT: disposition to trust, Rl: repurchase intention, SI: switching intention, TBS: transaction-based satisfaction

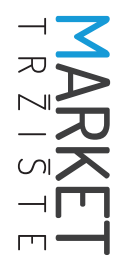




\subsection{Structural model analysis}

This structural model analysis (SEM) was examined using three different types of online hotel reservation platforms (OTA, P2P accommodation, and $\mathrm{VHO}$ ), with 200 respondents for each type of platform. The hypotheses testing was also carried out on those three platforms. The result of the SEM analysis is shown in Figure 1. There are different results in the relationship between variables in three different online hotel reservation platforms.

FIGURE 1: SEM analysis of the research model

a)

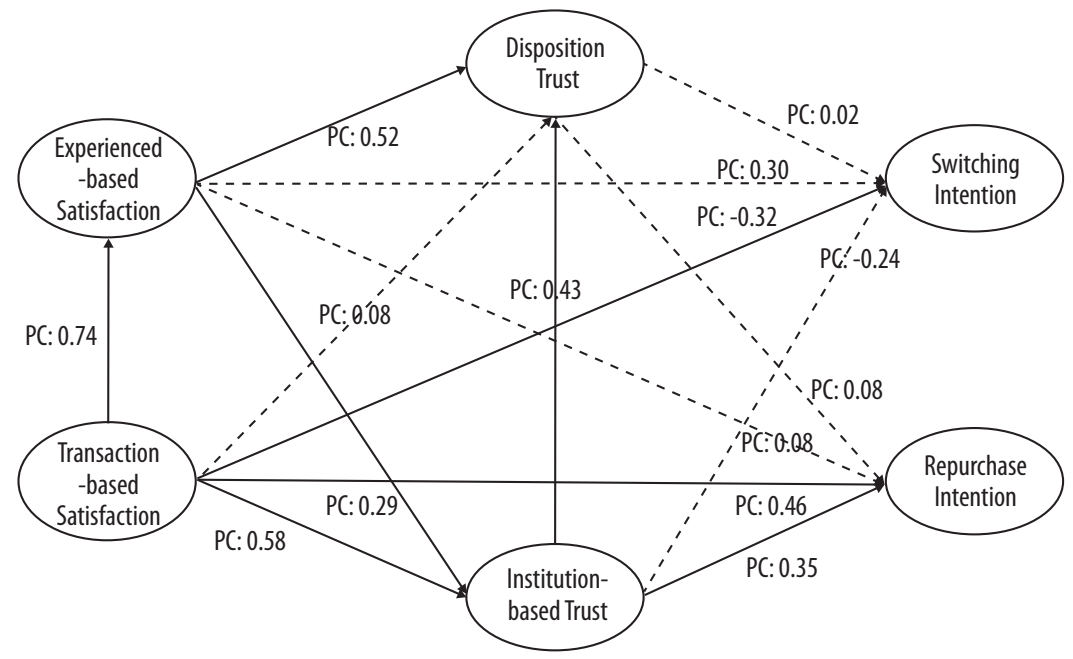

RMSEA $=0.076$

SRMR $=0.46$

$\mathrm{CFI}=0.98$

$\mathrm{NFI}=0.96$

$\mathrm{NNFI}=0.98$

Normed Chi

Square $=2.15$

$\mathrm{PNFI}=0.86$

b)

Peer-to-Peer Accomodation

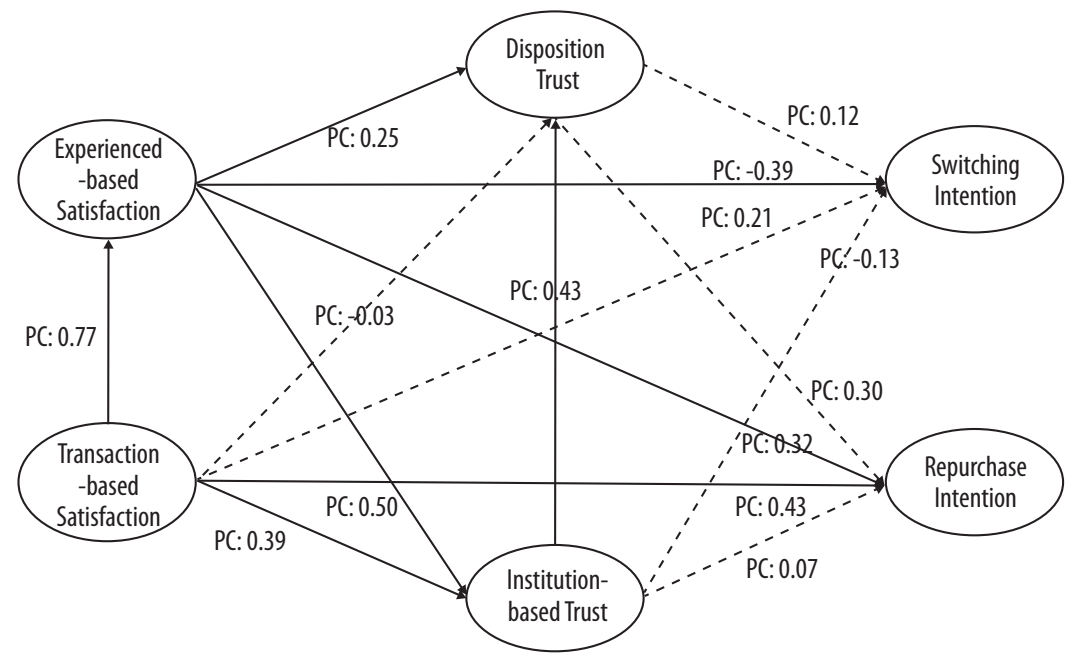

RMSEA $=0.075$

SRMR $=0.04$

$\mathrm{CFI}=0.98$

$\mathrm{NFI}=0.96$

$\mathrm{NNFI}=0.98$

Normed Chi

Square $=2.12$

$\mathrm{PNFI}=0.86$

PC : Path Coefficient 
c)

\section{Virtual Hotel Operator}

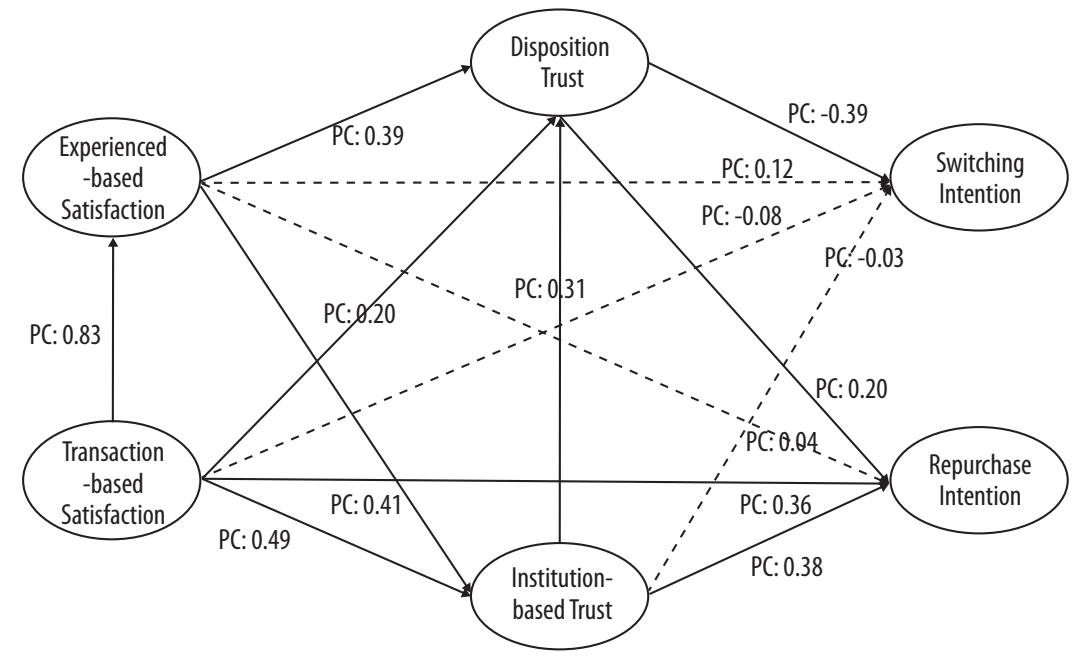

RMSEA $=0.077$

SRMR $=0.04$

$\mathrm{CFI}=0.98$

$\mathrm{NFI}=0.97$

$\mathrm{NNFI}=0.98$

Normed Chi

Square $=2.17$

$\mathrm{PNFI}=0.86$

PC : Path Coefficient

— : Significant

-.. - : Not significant

The OTA group had the following goodnessof-fit results: RMSEA was 0.076, SRMR was 0.46, $\mathrm{CFI}$ came in at 0.98, NFI stood at 0.96, NNFI/TLI at 0.98, the Normed Chi-Square was 2.15, and PNF was 0.86. The P2P accommodation group goodness-of-fit results were follows: RMSEA was 0.075 , SRMR was 0.04, CFI came in at 0.98, NFI was 0.96, NNFI/TLI was 0.98, the Normed Chi-Square stood at 2.12, and PNFI at 0.86. The VHO group had the following goodness-of-fit results: RMSEA was 0.077, SRMR was 0.04, CFI came in at 0.98, NFI was 0.97, NNFI/TLI was 0.98, the Normed ChiSquare stood at 2.17, and PNFI at 0.86 .

As shown in Figure 1a, in the OTA group, experience-based satisfaction had a positive impact on disposition to trust and institution-based trust, thereby validating $\mathrm{H} 1 \mathrm{a}$ and $\mathrm{H} 1 \mathrm{~b}$ (t-values: 5.69, 3.55), whereas experience-based satisfaction had no positive influence on switching intention or repurchase intention (t-values: 1.92, 0.92); thus, H1c and H1d were rejected. Transaction-based satisfaction had a positive influence on experience-based satisfaction, institution-based trust, repurchase intention, while showing a negative influence on switching intention, thereby validating $\mathrm{H} 2 \mathrm{a}, \mathrm{H} 2 \mathrm{C}, \mathrm{H} 2 \mathrm{~d}$, and H2e (t-values: 10.01, 6.73, 5.07, -2.07). Trans- action-based satisfaction had no influence on disposition to trust, so H2b was rejected. Disposition to trust showed no influence on switching and repurchase intentions (t-values: 0.13, 0.90), thereby rejecting $\mathrm{H} 3 \mathrm{a}$ and $\mathrm{H} 3 \mathrm{~b}$. Institution-based trust had a positive influence on disposition to trust and repurchase intention (t-values: 4.35, 3.70; $\mathrm{H} 4 \mathrm{a}$ and $\mathrm{H} 4 \mathrm{C}$ accepted) while showing no significant influence on switching intention (t-values: -1.48 ; $\mathrm{H} 4 \mathrm{~b}$ rejected).

In the P2P accommodation group, Figure 1b shows that experience-based satisfaction had a significant positive influence on disposition to trust, institution-based trust, and repurchase intention (t-values: 2.55, 5.79, 3.06; H1a, H1b, and $\mathrm{H} 1 \mathrm{~d}$ accepted) but a negative influence on switching intention (t-values: -2.14; H1c accepted). Transaction-based satisfaction was found to have a significant positive influence on experience-based satisfaction, institution-based trust, and repurchase intention (t-values: 10.67, 4.54, 4.38; $\mathrm{H} 2 \mathrm{a}, \mathrm{H} 2 \mathrm{c}$, and $\mathrm{H} 2 \mathrm{e}$ accepted) but no significant effect on disposition to trust or switching intention (t-values: $-0.38,1.27 ; \mathrm{H} 2 \mathrm{~b}$ and $\mathrm{H} 2 \mathrm{~d}$ rejected). Disposition to trust had no significant influence on switching intention of repurchase intention (t-values: 1.80, 1.27); thus, $\mathrm{H} 3 \mathrm{a}$ and $\mathrm{H} 3 \mathrm{~b}$ 
TABLE 3: Hypotheses Conclusion of the Three Platforms

\begin{tabular}{|c|c|c|c|c|c|c|}
\hline \multirow[t]{2}{*}{ Path } & \multicolumn{2}{|c|}{$\begin{array}{c}\text { Online Travel } \\
\text { Agent }\end{array}$} & \multicolumn{2}{|c|}{$\begin{array}{c}\text { P2P } \\
\text { Accommodation }\end{array}$} & \multicolumn{2}{|c|}{$\begin{array}{c}\text { Virtual Hotel } \\
\text { Operator }\end{array}$} \\
\hline & t-values & conclusion & $t$-values & conclusion & t-values & conclusion \\
\hline $\begin{array}{l}\text { Experience-based } \\
\text { satisfaction } \rightarrow \\
\text { Disposition to trust }\end{array}$ & 5.69 & $\begin{array}{c}\text { H1a } \\
\text { accepted }\end{array}$ & 2.55 & $\begin{array}{c}\text { H1a } \\
\text { accepted }\end{array}$ & 3.84 & $\begin{array}{c}\text { H1a } \\
\text { accepted }\end{array}$ \\
\hline $\begin{array}{l}\text { Experience-based } \\
\text { satisfaction } \rightarrow \\
\text { Institution-based trust }\end{array}$ & 3.55 & $\begin{array}{c}\text { H1b } \\
\text { accepted }\end{array}$ & 5.79 & $\begin{array}{c}\text { H1b } \\
\text { accepted }\end{array}$ & 4.40 & $\begin{array}{c}\text { H1b } \\
\text { accepted }\end{array}$ \\
\hline $\begin{array}{l}\text { Experience-based } \\
\text { satisfaction } \rightarrow \\
\text { Switching intention }\end{array}$ & 1.92 & $\begin{array}{l}\mathrm{H} 1 \mathrm{c} \\
\text { rejected }\end{array}$ & -2.14 & $\begin{array}{c}\text { H1c } \\
\text { accepted }\end{array}$ & 0.59 & $\begin{array}{l}\mathrm{H} 1 \mathrm{c} \\
\text { rejected }\end{array}$ \\
\hline $\begin{array}{l}\text { Experience-based } \\
\text { satisfaction } \rightarrow \\
\text { Repurchase intention }\end{array}$ & 0.92 & $\begin{array}{l}\text { H1d } \\
\text { rejected }\end{array}$ & 3.06 & $\begin{array}{c}\text { H1d } \\
\text { accepted }\end{array}$ & 0.40 & $\begin{array}{l}\text { H1d } \\
\text { rejected }\end{array}$ \\
\hline $\begin{array}{l}\text { Transaction-based } \\
\text { satisfaction } \rightarrow \\
\text { Experience-based } \\
\text { satisfaction }\end{array}$ & 10.01 & $\begin{array}{c}\mathrm{H} 2 \mathrm{a} \\
\text { accepted }\end{array}$ & 10.67 & $\begin{array}{c}\mathrm{H} 2 \mathrm{a} \\
\text { accepted }\end{array}$ & 11.79 & $\begin{array}{c}\mathrm{H} 2 \mathrm{a} \\
\text { accepted }\end{array}$ \\
\hline $\begin{array}{l}\text { Transaction-based } \\
\text { satisfaction } \rightarrow \\
\text { Disposition to trust }\end{array}$ & -0.86 & $\begin{array}{l}\mathrm{H} 2 \mathrm{~b} \\
\text { rejected }\end{array}$ & -0.38 & $\begin{array}{l}\mathrm{H} 2 \mathrm{~b} \\
\text { rejected }\end{array}$ & 1.88 & $\begin{array}{c}\mathrm{H} 2 \mathrm{~b} \\
\text { accepted }\end{array}$ \\
\hline $\begin{array}{l}\text { Transaction-based } \\
\text { satisfaction } \rightarrow \\
\text { Institution-based trust }\end{array}$ & 6.73 & $\begin{array}{c}\mathrm{H} 2 \mathrm{c} \\
\text { accepted }\end{array}$ & 4.54 & $\begin{array}{c}\mathrm{H} 2 \mathrm{c} \\
\text { accepted }\end{array}$ & 5.15 & $\begin{array}{c}\mathrm{H} 2 \mathrm{C} \\
\text { accepted }\end{array}$ \\
\hline $\begin{array}{l}\text { Transaction-based } \\
\text { satisfaction } \rightarrow \\
\text { Switching intention }\end{array}$ & -2.07 & $\begin{array}{c}\mathrm{H} 2 \mathrm{~d} \\
\text { accepted }\end{array}$ & 1.27 & $\begin{array}{l}\mathrm{H} 2 \mathrm{~d} \\
\text { rejected }\end{array}$ & -0.39 & $\begin{array}{l}\mathrm{H} 2 \mathrm{~d} \\
\text { rejected }\end{array}$ \\
\hline $\begin{array}{l}\text { Transaction-based } \\
\text { satisfaction } \rightarrow \\
\text { Repurchase intention }\end{array}$ & 5.07 & $\begin{array}{c}\text { H2e } \\
\text { accepted }\end{array}$ & 4.38 & $\begin{array}{c}\mathrm{H} 2 \mathrm{e} \\
\text { accepted }\end{array}$ & 3.34 & $\begin{array}{c}\text { H2e } \\
\text { accepted }\end{array}$ \\
\hline $\begin{array}{l}\text { Disposition to trust } \rightarrow \\
\text { Switching intention }\end{array}$ & 0.13 & $\begin{array}{c}\mathrm{H} 3 \mathrm{a} \\
\text { rejected }\end{array}$ & 1.80 & $\begin{array}{l}\mathrm{H} 3 \mathrm{a} \\
\text { rejected }\end{array}$ & -2.13 & $\begin{array}{c}\mathrm{H} 3 \mathrm{a} \\
\text { accepted }\end{array}$ \\
\hline $\begin{array}{l}\text { Disposition to trust } \rightarrow \\
\text { Repurchase intention }\end{array}$ & 0.90 & $\begin{array}{l}\mathrm{H} 3 \mathrm{~b} \\
\text { rejected }\end{array}$ & 1.27 & $\begin{array}{l}\mathrm{H} 3 \mathrm{~b} \\
\text { rejected }\end{array}$ & 2.22 & $\begin{array}{c}\mathrm{H} 3 \mathrm{~b} \\
\text { accepted }\end{array}$ \\
\hline $\begin{array}{l}\text { Institution-based trust } \\
\rightarrow \text { Disposition to trust }\end{array}$ & 4.35 & $\begin{array}{c}\mathrm{H} 4 \mathrm{a} \\
\text { accepted }\end{array}$ & 6.15 & $\begin{array}{c}\mathrm{H} 4 \mathrm{a} \\
\text { accepted }\end{array}$ & 2.96 & $\begin{array}{c}\mathrm{H} 4 \mathrm{a} \\
\text { accepted }\end{array}$ \\
\hline $\begin{array}{l}\text { Institution-based } \\
\text { trust } \rightarrow \text { Switching } \\
\text { intention }\end{array}$ & -1.48 & $\begin{array}{l}\mathrm{H} 4 \mathrm{~b} \\
\text { rejected }\end{array}$ & -0.62 & $\begin{array}{l}\mathrm{H} 4 \mathrm{~b} \\
\text { rejected }\end{array}$ & -0.14 & $\begin{array}{l}\mathrm{H} 4 \mathrm{~b} \\
\text { rejected }\end{array}$ \\
\hline $\begin{array}{l}\text { Institution-based } \\
\text { trust } \rightarrow \text { Repurchase } \\
\text { intention }\end{array}$ & 3.70 & $\begin{array}{c}\mathrm{H} 4 \mathrm{c} \\
\text { accepted }\end{array}$ & 0.56 & $\begin{array}{l}\mathrm{H} 4 \mathrm{c} \\
\text { rejected }\end{array}$ & 3.54 & $\begin{array}{c}\mathrm{H} 4 \mathrm{c} \\
\text { accepted }\end{array}$ \\
\hline
\end{tabular}


were rejected. Institution-based trust had a significant positive influence on disposition to trust (t-values: 6.15; H4a accepted), but no significant effect on switching or repurchase intention (t-values: $-0.62,0.56)$, so $\mathrm{H} 4 \mathrm{~b}$ and $\mathrm{H} 4 \mathrm{c}$ were rejected.

Figure 1c shows that, in the VHO group, experience-based satisfaction had a positive influence on disposition to trust and institution-based trust (t-values: 3.84, 4.40; H1a and H1b accepted) but no significant effect on switching or repurchase intentions (t-values: 0.59, 0.40); thus, $\mathrm{H} 1 \mathrm{C}$ and H1d were rejected. Transaction-based satisfaction had a positive influence on experience-based satisfaction, disposition to trust, institution-based trust, and repurchase intention (t-values: 11.79, 1.88, 5.15; H2a, H2b, H2c, and $\mathrm{H} 2 \mathrm{e}$ accepted) but no significant effect on switching intention (t-values: $-0.39 ; \mathrm{H} 2 \mathrm{~d}$ rejected). Disposition to trust had a significant negative influence on switching intention and a positive influence on repurchase intention (t-values: -2.13, 2.22); thus, we could accept H3a and H3b. Institution-based trust had a significant positive influence on disposition to trust and repurchase intention (t-values: 2.96, 3.54; $\mathrm{H} 4 \mathrm{a}$ and $\mathrm{H} 4 \mathrm{c}$ accepted) but was found to have no significant effect on switching intention (t-values: -0.14), so H4b was rejected. The full conclusion of the hypotheses on those three platforms is shown in Table 3.

\section{DISCUSSION}

\subsection{Theoretical implications}

The purpose of this study is to determine the effect of satisfaction and trust on repurchase intention and switching for three different types of platforms: OTA, peer-to-peer accommodation, and $\mathrm{VHO}$. The findings indicated some differences in each of the factors that influenced repurchase intention and switched in all three types of platforms.

Experience-based satisfaction affected repurchase intention and had a negative effect on switching intention only on peer-to-peer accom- modation platforms. The findings of this study extend the previous research conducted by Liang et al. (2018); however, experience-based satisfaction was not found to be a critical factor of switching intention or repurchase intention on OTA and VHO platforms. Properties that were rented through these platforms were hotel rooms, where one hotel room was rented through several providers. In other words, there was nothing unique in terms of experience-based satisfaction because several providers sold the same product (room).

Moreover, experience-based satisfaction had a positive effect on disposition to trust and institution-based trust in all three types of platforms. The results are consistent with the results of the research conducted by Fang et al. (2014), who examined the mechanism of transactions in the e-commerce industry, where customer satisfaction with the vendor would affect the level of customer confidence in the vendor. Furthermore, Walczuch and Lundgren (2004) stated that the level of trust in e-retailing companies was influenced by several important factors: satisfaction and experience when shopping through e-retailing services.

Transaction-based satisfaction had a negative influence on switching intention only on OTA platforms but had a positive effect on repurchase intention on all the three platforms. This study had similar findings with the study by Liang et al. (2018), who concluded that in order to prevent switching intentions, companies should maintain customer satisfaction, especially on the side of their transaction activities with the company. OTAs have the advantage of providing structured transaction mechanisms, ranging from the ease of obtaining information, the accuracy of information, and the speed of transaction processing.

In addition, transaction-based satisfaction had a positive effect on disposition to trust only on $\mathrm{VHO}$ platforms. The three types of platforms had differences based on their business model. OTA and peer-to-peer accommodation had a role as a marketplace, so the company did not

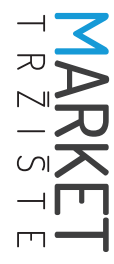




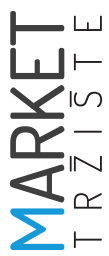

set standards for all room facilities that were rented out through those platforms. This meant that the evaluation of customer satisfaction with the transaction process and activities with the company did not affect the level of trust in the host on OTA and peer-to-peer accommodation platforms; basically, the two parties are different parties, so customers have different views of the company's transaction process and trust in the host. This can be minimized on the $\mathrm{VHO}$ platform, where the VHO company sets standards for all hosts and room facilities for rent. Thus, although the two parties are different but share the same standardization characteristics, customers' level of trust in the host was formed based on the process and transaction activities with the company. However, transaction-based satisfaction had a positive effect on institution-based trust in all three types of platforms.

Disposition to trust had a positive effect on repurchase intention but a negative effect on switching intention only on $\mathrm{VHO}$ platforms. These results are consistent with those of the research study by Liang et al. (2018), showing the level of customer trust in the host to be one of the key factors to encourage customers not to switch to other service providers. However, on the OTA and peer-to-peer accommodation platforms, the trust variable was not too strong in maintaining a low level of switching intention compared with the satisfaction variable (both transaction-based and experience-based); this is similar to the results of the research conducted by Ranaweera and Prabhu (2003).

Institution-based trust had no significant effects on switching intention in all three types of platforms. These findings were in line with the research conducted by Liang et al. (2018), who stated that there was no effect of institution-based trust on switching intention. Customers needed a lot of information to switch to another service provider and would consider many factors, such as switching costs or easiness of use on other platforms; thus, institution-based trust was not found to be the main factor of switching intentions for customers.
Finally, the present study indicated that institution-based trust had a positive relationship with repurchase intention in two types of platform: OTA and VHO platforms. These findings were also found in the research study by Jia et al. (2014), which analyzed the influence of institution-based trust on repurchase intention. This is the main reason for the companies to stimulate the level of institution-based trust if they want to obtain the high probability of repurchase interest.

\subsection{Managerial implications}

Based on the analysis presented in the previous discussion, several findings could be used to provide insight or suggestion to companies that operate online booking platforms. OTA, peerto-peer accommodation, and $\mathrm{VHO}$ all have different factors that increase repurchase intention and decrease switching intention.

The OTA platform has an important aspect that should be considered when attempting to increase customer repurchase intention and decrease switching intention, that is, transaction-based satisfaction. Complete information about lodging (hotel rooms) provided on the OTA site is the most important factor in transaction-based satisfaction. Therefore, OTA companies should put more effort into coordinating with hotel partners to make regular updates if there is a change in information on the lodging side. Information that can be added to each hotel site in the OTA platform is the route or public transportation that can be used to get to the hotel. Then information about leisure facilities such as swimming pools, lobby areas, or gym areas should also be included.

Increasing repurchase intention in the case of peer-to-peer accommodation platform can be done by increasing experience-based satisfaction as one of the most important aspects. This can also be done to prevent customer switching intention in P2P accommodation platform. The input on this side is the process of interaction between hosts and customers, especially in hospitality and service aspects. In general, P2P platforms offer overnight stays by providing strong 
local experience and culture experience, so the company should arrange a standard operating system (SOP) which would include guidelines for the host to have a good interaction with the customers.

VHO companies can increase customer repurchase intention by maintaining the customer's transaction-based satisfaction, especially with the service mechanism provided by the company. The thing that needs to be improved in this aspect is that the company should add the contact number of each hotel's (host's) partner. Also, to prevent customer switching intention, the company should increase customer trust toward hotels (hosts) partner. This can be done by providing a guarantee to the customers that the hosts have good integrity. Companies can add a rating system on their platform for each hotel partner.

\subsection{Limitations and further research}

Each study has its own limitations during the development process. First, this study focused on three different platforms of online hotel reservation, where the respondents were divided based on those types of platform rather than by company. Two different companies on the same type of platform tend to have different levels of evaluation by respondents. Second, this study was able to prove the relationship between variables but could not explore more specifically the different relationships between the variables on those three types of platforms. This study also failed to provide the reason why those differences existed. Third, this study only involved Indonesian respondents and companies operating online booking platforms in Indonesia, so its findings cannot be generalized to represent conditions throughout the world. Respondents' perception in different cultures are likely to produce influence differences in answers from those found in this study.
Further research of online hotel booking companies, not just platform types, should also be beneficial because different companies using the same type of platform will result in different responses given by respondents when evaluating their experiences. In addition, this research model can be applied to other industries with similar online transaction system. Future research can develop and add other types of platforms using new business models. It should be done because this industry is one of the fastest growing industries and has numerous new growing companies with new business models. One of the recommendations is a collaborate-living platform type. Finally, this study uses quantitative research methods, so it cannot explain specifically the reasons behind the differences in relationships between variables on the three platforms; therefore, it is recommended to use qualitative research methods to explore those reasons in more detail.

\section{CONCLUSIONS}

The aspects of satisfaction and trust had a positive impact on customer repurchase intention but a negative impact on switching intention; however, these results may differ for each type of platforms (OTA, peer-to-peer accommodation, and $\mathrm{VHO}$ ).

On the OTA platform, transaction-based satisfaction was found to be the most important factor likely to reduce customer repurchase intention and switching intention. Meanwhile, when it comes to peer-to-peer accommodation, experience-based satisfaction was the key factor of influence on customer repurchase intention and the one that can reduce customer switching intention. Furthermore, the results revealed disposition to trust as the most important factor for intensifying repurchase intention and reducing switching intention. 


\section{References}

1. Bart, Y., Venkatesh, S., Sultan, F., \& Urban, G. (2005). Are the drivers and role of online trust the same for all web sites and consumers? A large scale exploratory empirical study. Journal of Marketing, 69, 133-152.

2. Berry, L. L. (1995). Relationship Marketing of Services - growing interest, emerging perspectives. Journal of the Academy of Marketing Science, 23(4), 236-245.

3. Berry, L. L. (2002). Relationship Marketing of Services - Perspectives from 1983 and 2000. Journal of Relationship Marketing, 1(1), 59-79.

4. Bicchieri, C., Duffy, J., \& Tolle, G. (2004). Trust among strangers. Philosophy Science, 71(3), 286-319.

5. Bitner, M. J., \& Hubbert, A. R. (1994). Encounter satisfaction versus overall satisfaction versus quality. In: R. T. Rust \& R. L. Oliver (Eds.), Service Quality: New Directions in Theory and Practice. Thousand Oaks, CA: Sage.

6. Botsman, R., \& Rogers, R. (2010). What's Mine Is Yours: The Rise of Collaborative Consumption. New York, NY: Harper Collins.

7. Cengiz, E. (2010). Measuring Customer Satisfaction. Journal of Naval Science and Engineering, 6(2), 76-88.

8. CNN Indonesia (2016). "Indonesia, Pasar Seksi bagi Bisnis Operator Hotel Virtual". Avaliable at: https://www.cnnindonesia.com/gaya-hidup/20160315105527-276-117472/indonesia-pasar-seksi-bagi-bisnis-operator-hotel-virtual (accessed October 19 $19^{\text {th }}, 2016$ )

9. Davis, F. D. (1989). Perceived usefulness, perceived ease of use, and user acceptance of information technology. MIS Quarterly, 13, 319-340.

10. Erdem, T., Louviere, J., \& Swait, J. (2002). The impact of brand credibility on consumer price sensitivity. International Journal of Research in Marketing, 19, 1-19.

11. Fang, Y., Qureshi, I., Sun, H., Mccole, P., Ramsey, E., \& Lim, K. H. (2014). Trust, Satisfaction, and Online Repurchase Intention: The Moderating Role of Perceived Effectiveness of E-commerce Institutional Mechanism. MIS Quarterly 38(2), 407-427.

12. Fornell, C., \& Larcker, D. F. (1981). Evaluating structural equation models with unobservable and measurement error. Journal of Marketing Research, 18,39-50.

13. Gao, B. W., \& Ka Wai Lai, I. (2015). The Effects of Transaction-specific Satisfaction and Integrated Satisfaction on Customer Loyalty. International Journal of Hospitality Management, 44, 38-47.

14. Guttentag, D. (2015). Airbnb: disruptive innovation and the rise of an informal tourism accommodation sector. Current Issues in Tourism, 18(12), 1192-1217.

15. Han, H., Kim, W., \& Hyun, S. S. (2011). Switching Intention Model Development: Role of Service Performances, Customer Satisfaction, and Switching Barriers in Hotel Industry. International Journal of Hospitality Management, 30, 619-629.

16. Haryono, S. (2017). Metode SEM untuk Penelitian Manajemen Amos Lisrel PLS [SEM Method for Management of Amos Lisrel PLS Research]. Jakarta: Luxima Metro Media.

17. Hicks, J. M., Page Jr., T. J., Behe, B. K., Dennis, J. H., \& Fernandez, T. R. (2005) Delighted Consumers Buy Again. Journal of Consumer Satisfaction, Dissatisfaction and Complaining Behavior, 18, 94-104.

18. Huang, Q., \& Robert, D. (2011). The Impact of Different Types of Satisfaction on C2C Platform Loyalty. $32^{\text {nd }}$ International Conference on Information Systems, Shanghai.

19. Igbaria, M., Zinatelli, N., Cragg, P., \& Cavaye, A. L. M. (1997). Personal Computing Acceptable Factors in Small Firms: A Structural Equation Model. MIS Quarterly, 21, 279-299.

20. Inversini, A., \& Lorenzo, M. (2013). Selling Rooms Online: The Use of Social Media and Online Travel Agents. International Journal of Contemporary Hospitality Management, 26(2), 272-292.

21. Jang, Y. J., Cho, S. B., \& Kim, W. G. (2013). Effect of restaurant patrons' regret and disappointment on dissatisfaction and behavioral intention. Journal of Travel \& Tourism Marketing, 30(5), 431-444. 
22. Jia, L., Cegielski, C., \& Zhang, Q. (2014). The effect of trust on customer's online repurchase intention in consumer-to-consumer electronic commerce. Journal of Organizational and End User Computing. 26(3), 65-86.

23. Keaveney S. M. (1995). Customer Switching Behavior in Service Industries: An Exploratory Study. Journal of Marketing, 59(2), 71-82.

24. Kesharwani, S., \& Vivek, K. (2016). On Your Own: An Oyo Story a Case Study. International Journal of Engineering and Management Research, 6(5), 325-331.

25. Kim, B., Kim, S., \& Yoonjoung Heo, C. (2017). Consequences of Customer Dissatisfaction in Upscale and Budget Hotels: Focusing on Dissatisfied Customers' Attitude Toward a Hotel. International Journal of Hospitality \& Tourism Administration, 20(1) 15-46.

26. Kim, D. J., Kim, W. G., \& Han, J. S. (2007). A perceptual mapping of online travel agencies and preference attributes. Tourism Management, 28(2), 591-603.

27. Kotler, P., \& Keller, K. (2012). Marketing Management. Boston, MA: Pearson Education.

28. Lee, J., \& Morrison, A. M. (2010). A comparative study of website performance. Journal of Hospitality and Technology, 1(1), 50-67.

29. Liang, L., Hwansuk, C., \& Marion, J. (2018). Exploring the relationship between satisfaction, trust and switching intention, repurchase intention in the context of Airbnb. International Journal of Hospitality Management, 69, 41-48.

30. Malhotra, N. (2010). Marketing Research an Applied Orientation. $6^{\text {th }}$ ed. New Jersey, NJ: Pearson.

31. Matute-Vallejo, J., Polo-Redondo, Y., \& Utrillas, A. (2016). The Influences of E-WOM Characteristics on Online Repurchase Intention: Mediating Roles of Trust and Perceived Usefulness. Online Information Review, 40(7), 1090-1110.

32. McKnight, D. H., Choudhury, V., \& Kacmar, C. (2002). Developing and validating trust measures for e-commerce: An integrative typology. Information Systems Research, 13(3), 334-359.

33. McKnight, D. H., Cummings, L. L., \& Chervany, N. L. (1998). Initial trust formation in new organizational relationships. Academy of Management Review, 23(3), 473-490.

34. Moorman, C., Zaltman, G., \& Deshpande, R. (1992). Relationships between providers and users of market research: the dynamics of trust within and between organizations. Journal of Marketing Research, 29(3), 314-328.

35. Morosan, C., \& Jeong, M. (2008). Users' perceptions of two types of hotel reservation web sites. International Journal of Hospitality Management, 27(2), 284-292.

36. Park, C. H., \& Young, G. K. (2003). Identifying Key Factors Affecting Consumer Purchase Behavior in an Online Shopping Context. International Journal of Retail \& Distribution Management, 31(1), 16-29.

37. Pavlou, P. A., Liang, H., \& Xue, Y. (2007). Understanding and mitigating uncertainty in online exchange relationships: A principal-agent perspective. MIS quarterly, 31(1), 105-136.

38. Peyrot, M., \& Van Doren, D. (1994). Effect of a Class Action Suit on Consumer Repurchase Intentions. Journal of Consumer Affairs, 28(2), 361-379.

39. Ranaweera, C., \& Prabhu, J. (2003). The influence of satisfaction, trust and switching barriers on customer retention in a continuous purchasing setting. International Journal of Service Industry Management, 14(4), 374-395.

40. Shankar, V., Smith, A. K., \& Rangaswamy, A. (2003). Customer Satisfaction and Loyalty in Online and Offline Environments. International Journal of Research in Marketing, 20, 153-175.

41. Shihab, M. R., Maulana, D., \& Hidayanto, A. N. (2018). Determinants of Repurchase Intention in C2C E-Commerce: Customer's Perspectives of Merchants and Platform Providers. Information Resources Management Journal, 31(3), 1-16. 
42. Thong, J. Y. L., Hong, S. J., \& Tam, K. Y. (2006). The Effects of Post-Adoption Beliefs on the Expectation-Confirmation Model for Information Technology Continuance. International Journal of Human-Computer Studies, 64(9), 799-810.

43. Trif, S. M. (2013). The Influence of Overall Satisfaction and Trust on Customer Loyalty. Journal of Management \& Marketing Challenges for the Knowledge Society, 8(1), 109-128.

44. Tussyadiah, I. P., \& Pesonen, J. (2016). Impacts of peer-to-peer accommodation use on travel patterns. Journal of Travel Research, 55(8), 1022-1040.

45. Tussyadiah, I. P. (2016). Factors of satisfaction and intention to use peer-to-peer accommodation. International Journal of Hospitality Management, 55, 70-80.

46. Walczuch, R., \& Lundgren, H. (2004). Psychological Antecedents of Institution-based Consumer Trust in E-retailing. Journal of Information \& Management, 42(1), 159-177.

47. Woodruff, R. B., Cadotte, E. R., \& Jenkins, R. L. (1983). Modeling consumer satisfaction processes using experience-based norms. Journal of Marketing Research, 20(3), 296-304.

48. www.DailySocial.id 